\title{
Honoré de Balzac, Papà Goriot
}

\section{Marco Stupazzoni}

\section{OpenEdition}

\section{Journals}

\section{Edizione digitale}

URL: http://journals.openedition.org/studifrancesi/5380

ISSN: 2421-5856

\section{Editore}

Rosenberg \& Sellier

\section{Edizione cartacea}

Data di pubblicazione: 1 dicembre 2016

Paginazione: 543

ISSN: 0039-2944

\section{Notizia bibliografica digitale}

Marco Stupazzoni, « Honoré de Balzac, Papà Goriot », Studi Francesi [Online], 180 (LX | III) | 2016, online dal 01 janvier 2017, consultato il 17 septembre 2020. URL : http://journals.openedition.org/ studifrancesi/5380

Questo documento è stato generato automaticamente il 17 settembre 2020 .

\section{(c) (i) (9)}

Studi Francesi è distribuita con Licenza Creative Commons Attribuzione - Non commerciale - Non opere derivate 4.0 Internazionale. 


\title{
Honoré de Balzac, Papà Goriot
}

\author{
Marco Stupazzoni
}

\section{NOTIZIA}

HONORÉ DE BALZAC, Papà Goriot, introduzione di Lanfranco Binni, traduzione di Elina Klersy Imberciadori, Milano, Garzanti, 2015, «I grandi libri», LXIV-247 pp.

1 La prima edizione di questa nuova traduzione di Le Père Goriot risale al 1990: le numerose ristampe del volume testimoniano il duraturo e pregnante successo del capolavoro balzachiano presso il pubblico italiano. L'ampia e curata introduzione di L. Binni traccia con equilibrio un accurato profilo biografico, storico e critico dello scrittore e della sua opera a partire dai primi romanzi giovanili.

2 A proposito di Le Père Goriot, L. Binni osserva che, proprio a partire da questo romanzo, Balzac «prende pienamente coscienza del carattere unitario della propria opera»e avverte di essere «l'autore di un unico grande mosaico, un sistema narrativo in cui ogni tassello, ogni personaggio, ogni "tema", entrano ormai spontaneamente in un rapporto di coerenza, coesistenza, contrasto» (p. LVII). Nello stesso breve capitolo dedicato al capolavoro di Balzac, dobbiamo segnalare il reiterarsi del rifuso tipografico relativo al nome «Vauquer», più volte trascritto erroneamente in «Vauqueur» (sic). La Guida bibliografica con la quale si completa questo saggio del Binni è aggiornata opportunamente dal curatore con nuovi riferimenti critico-bibliografici a partire dal xXI secolo (pp. LXIII-LXIV). 